\title{
PERKEMBANGAN SOSIAL EMOSIONAL ANAK USIA DASAR DI LINGKUNGAN KELUARGA
}

\author{
Ruja Wati \\ Universitas Islam Negeri Sunan Kalijaga Yogyakarta \\ rujawati07@gmail.com
}

\begin{abstract}
Children in a family environment that is less harmonious, the most important thing the child expresses is feelings of anger or sadness when someone asks it and this will affect the social to others. Therefore it is necessary to have an environment that is able to direct the child's social emotional direction in a positive direction. the family environment is very influential on the child's social emotional, when the child is in the family environment such as conflicts between families, lack of communication in the family, and so on actually the child's emotional emotional needs are not met. So the focus of problem is how elementary age children must have a good social emotional that is by providing a good environment as well as parenting parents themselves. For this reason the approach used is a qualitative approach with the method of field study with the data collection technique is interview. According to data in the field that the social emotional development of children who are socially emotionally good are parents giving examples, advice and examples from their own environment that show the goodness of kindness. And give examples of examples in daily life such as greeting, being honest and not distinguishing friends. So that children's emotions can be controlled well because they are always careful and not selfish, which later gives birth to good social towards parents, siblings and even peer friends.
\end{abstract}

Keywords: Development, Emotional Social, Family Environment

\begin{abstract}
Abstrak : Anak dalam lingkungan keluarga yang kurang harmonis, hal yang paling utama anak tersebut ungkapkan adalah perasaan marah ataupun sedih ketika seseorang menanyakan hal tersebut dan hal ini akan berpengaruh terhadap sosialnya terhadap orang lain. Oleh sebab itu perlu adanya lingkungan yang mampu mengarahkan social emosional anak tersebut kearah yang positif. lingkungan keluarga sangat berpengaruh pada social emosional anak, ketika anak berada didalam lingkungan keluarga seperti terjadi konflik antara keluarga, kurangnya komunikasi dalam keluarga, dan sebagainya sebenarnya kebutuhan social emosional anak tidak terpenuhi. Maka focus permaslahannya adalah bagaimana anak usia dasar harus memiliki social emosional yang baik yaitu dengan cara memberikan lingkungan yang bai pula serta pola asuh orang tua itu sendiri. Untuk itu pendekatan yang digunakan adalah pendekatan kualitatif dengan metode studi lapangan dengan teknik pengumpulan datanya adalah wawancara. Menurut data dilapangan bahwa perkembangan social emosional anak yang social emosionalnya baik adalah orang tua memberikan contoh, nasihat serta contoh darilingkungan sendiri yang memperlihatkan kebaikan kebaikan. Dan memeberikan contoh keteladanan didalam kehidupan sehari-hari seperti menyapa, jujur serta tidak memebedakan teman. Sehingga emosi anak mampu terkontrol dengan baik karena selalu berhati-hati serta tidak egois, yang nantinya melahirkan social yang baik terhadap orang tua, saudara dan bahkan teman sebaya.
\end{abstract}

Kata Kunci: Perkembangan, Sosial Emosional, Lingkungan Keluarga

PALAPA : Jurnal Studi Keislaman dan Ilmu Pendidikan

Volume 8, Nomor 2, November 2020; p-ISSN 2338-2325; e-ISSN 2540-9697; 369-382

https:/ / ejournal.stitpn.ac.id/index.php/palapa 


\section{PENDAHULUAN}

Perkembangan sosial emosional anak merupakan suatu keadaan yang ada pada diri anak yang meliputi perubahan secara badaniah maupun kondisi mental yang nantinya menimbulkan rasa seperti sedih, marah, bahagia, tidak bertanggung jawab, susah mengambil keputusan dan sebagainya. Didalam perkembangan dunia pendidikan sosial-emosional memasuki kedudukan yang sangat penting selain perkembangan kognitif anak. Oleh sebab itu perkembagan sosial-emosional anak sangat berpengaruh baik itu di lingkungan sekolah maupun di lingkungan keluarga dan masyarakat. Perkembangan sosial-emosional anak usia dasar sangat berpengaruh kepada perilaku, penyesuaian, pengendalian, serta dengan aturan-aturan. Ketika anak mampu mengkondisikan diri dengan lingkungannya maka fungsi sosial-emosionalnya juga akan semakin baik. Perkembangan sosial-emosional anak sangat dipengaruhi oleh beberapa faktor yaitu faktor lingkungan sosial dan lingkungan keluarga.

Didalam tahapan perkembangan sosial-emosional tidak semua anak mampu melewati perkembangan dengan baik, disisi lain anak mengalami suatu permasalahan untuk mengembangkan sosial-emosional dikarenakan adanya pengaruh negatif dari dalam lingkungan sosial serta keluarga yang kurang mendukung. Oleh sebab itu peran orang tua sangat berpengaruh terhadap perkembangan sosial-emosi anak usia dasar yaitu dengan cara memberi bimbingan serta pengarahan terhadap perkembangan sosialemosional anak usia dasar guna tercapainya tujuan akhir yaitu perkembangan sosialemosional yang diharapkan.

Emosi anak itu timbul dikarenakan ketidak siapan anak dalam menyikapi kondisi lingkungan sekitar. ${ }^{1}$ Adapun perkembangan emosi anak dipengaruhi oleh factor kematangan dan factor belajar. Factor kematangan berpengaruh terhadap respon individu dalam menyikapi berbagai keadaan yang dihadapi, baik dari dalam diri maupun konflik-konflik dalam proses perkembangan yang terjadi. Sedangkan factor belajar diperoleh dari lingkungan yang ada disekitar anak, terutama lingkungan yang berada dalam mikrosistem, mesosistem, ekosistem, makrosistem, dan kronosistem yaitu salah satunya adalah lingkungan keluarga dimana anak itu tinggal (mikrosistem).

1 Riana Masher, "Emosi Anak Usia Dini Dan Pengembangannya" Jakarta: Kencana Prenada Group, 2011), Hlm 3. 
Adapun kenyataan ataupun fakta yang sering kita jumpai bahwasannya anak sering kali marah ketika ada sesuatu yang membuat perasaannya terganggu seperti ditanyai masalah orang tuanya atau keluarganya. Dalam hal ini ketika anak itu dalam lingkungan keluarga yang kurang harmonis, maka hal yang paling utama anak tersebut ungkapkan adalah perasaan marah ataupun sedih ketika seseorang menanyakan hal tersebut dan hal ini akan berpengaruh terhadap sosialnya terhadap orang lain. Oleh sebab itu perlu adanya lingkungan yang mampu mengarahkan social emosional anak tersebut kearah yang positif. lingkungan keluarga sangat berpengaruh pada social emosional anak, ketika anak berada didalam lingkungan keluarga seperti terjadi konflik antara keluarga, kurangnya komunikasi dalam keluarga, dan sebagainya sebenarnya kebutuhan social emosional anak tidak terpenuhi. Adapun anak yang dikatakan social emosional nya baik adalah ketika anak tersebut mampu merealisasikan sosial emosionalnya kearah yang positif. Maka dari itu perlu adanya lingkungan yang baik untuk perkembangan anak baik prasekolah maupun sudah sekolah atau bahkan anak yang sudah dewasa sekalupun. Karena pertumbuhan anak itu baik atau tidaknya prilaku yang ia miliki tergantung pada lingkungan sekitarnya.

Sosial emosional pada anak usia dasar, perkembangan sosialnya sudah mulai bisa berkompetensi dengan teman sebaya, mempunyai sahabat, telah mampu mandiri dan berbagi. Sementara dari segi emosionalnya anak sekolah dasar sudah dapat mengekspresikan maupun mengontrol emosinya melalui meniru maupun pembiasaan. ${ }^{2}$ Oleh sebab itu didalam lingkungan keluarga itu lah anak diberi pengajaran dengan pembiasaan-pembiasaan yang baik seperti saling menyayangi antara sesama saudaranya guna untuk mendapatkan social yang baik, diajarkan bagaimana cara menahan amarah ketika ada masalah guna untuk mengontrol emosinya, dan lain sebagainya. Karena itu emosi, dibutuhkan lingkungan yang mendukung agar anak mendapatkan emosi yang baik yang sesuai dengan kapasitas anak tersebut. Dengan demikian lingkungan keluarga adalah salah satu pondasi awal untuk pembentukan social emosional anak kearah yang positif. Oleh karena itu adapun tujuan dari jurnal ini adalah untuk mengetahui bagaimana perkembangan social emosional pada anak usia dasar dilingkungan keluarga serta untuk mengetahui apasajakah hal yang harus dilakukan oleh keluarga agar social

2 Dkk Eka Tusyana, “'Analisis Perkembangan Social Emosional Tercapai Usia Dasar,” Jurnal Inventa Vol III No (2019): 21-22. 
emosional anak usia dasar tersebut terarahkan kearah yang positif guna untuk perkembangan fisik dan mentalnya dikemudian hari.

\section{METODE}

Adapun penelitian ini menggunakan pendekatan kualitatif dengan metode yang digunakan adalah studi lapangan. ${ }^{3}$ Teknik pengumpulan data dengan cara wawancara melalui beberapa keluarga, serta buku dan sumber literasi yang terkait dengan perkembangan social emosional anak usia dasar di lingkungan keluarga. Analisis data dilakukan dengan mengkaji konsep perkembangan social emosional.

\section{HASIL DAN PEMBAHASAN}

\section{Hasil}

Menurut hasil wawancara dengan beberapa keluarga yang terdapat di Yogyakarta bahwasannya ada dua jenis social emosional anak yaitu anak yang mampu dalam mengontrol emosionalnya sehingga sosialnya dengan lingkungan keuarganya pun terbilang bagus, dan ada anak yang belum mampu mengontrol emosionalnya sehingga sosialnya dengan lingkungan maupun saudara yang ada disekitarnya kurang bagus. Adapun anak yang social emosionalnya baik menurut wawancara langsung dengan orang tua maupun saudara anak tersebut bahwasanya keluarga sangat memperhatikan ataupun sangat peduli terhadap anak tersebut. Adapun upaya orang tua agar anak memiliki social emosional yang baik yaitu dengan cara memberikan contoh, nasihat serta contoh dari lingkungan sendiri yang memperlihatkan kebaikan kebaikan. Dan memeberikan contoh keteladanan didalam kehidupan sehari-hari seperti menyapa, jujur serta tidak memebedakan teman. Sehingga emosi anak mampu terkontrol dengan baik karena selalu berhati-hati serta tidak egois, yang nantinya melahirkan social yang baik terhadap orang tua, saudara dan bahkan teman sebaya.

Adapun anak yang social emosionalnya kurang baik dipengaruhi oleh lingkungan yang kurang mendukung. Menurut wawancara orang tua maupun saudara, anak yang social emosionalnya kurang terkontol adala ketika anak kurang mendapatkan perhatian dari

3 A Prastowo, Menyusun Rencana Pelaksanaan Pembelajaran (RPP) Tematik Terpadu (Jakarta: Prenada Media Group, 2017).Hlm.5 
lingkungan keluarga terutama orang tua. Contohnya menskipun orang tua sudah mendaftarkan anaknya ke TPA/ tempat mengaji, disekolahkan di tempat yang bagus, akan tetapi ketika di rumah dilingkungan keluarganya kurang peduli terhadap apa yang dia lakukan, maka hal inilah yang menjadi penyebab kenapa anak tersebut social emosionalnya kurang baik. Sehingga anak akan cendrung jadi pemarah, suka mengatur, dan terkadang sering bertengkar dengan saudara kandungnya dan bahkan tidak mau mendengarkan nasihat orang tuanya.

Oleh karena itu peran keluarga sangatlah penting terhadap perkembangan social emosional anak terlebih lagi pada anak usia dasar. Orang tua maupun saudara yang ada dilingkungan keluarga tersebut harus sangat memeperhatikan dan peduli terhadap anak agar anak mampu mengontrol emosionalnya sehingga nantinya akan mampu menghasilkan social yang baik dan mampu menjadi teladan bagi siapapun yang melihat anak tersebut. Bukan saja keluarga yang senang maupun mengingin anak yang sosialnya baik dan mampu mengontrol emosinya, akan tetapi orang lain yang ada disekitar pekarang rumah tempat anak itu tinggal juga akan menjadikan anak tersebut sebagai suri tauladan bagi anak-anak mereka.

\section{Pembahasan}

\section{Pengertian perkembangan}

Perkembangan adalah hal yang berkaitan dengan perubahan kualitatif serta kuantitatif yaitu urutan progresif dari perubahan yang teratur serta koheren. Progresif itu ditandai dengan adanya perubahannya yang terarah, membimbing anak untuk maju. Adapun teratur dan koheren menunjukkan bahwa adanya keterkaitan nyata antara perubahan yang sebelumnya maupun sesudahnya. Ada beberapa karakteristik dari perkembangan perkembangan yaitu sebagai berikut:

a. Perkembangan itu berlangsung dimulai dari hal-hal yang bersifat umum kemudian ke sifat khusus.

b. Perkembangan itu bersifat berkesinambungan.

c. Setiap bagian tubuh memiliki kecepatan pertumbuhan masing-masing

d. Selalu ada hubungan antara perkembangan yang semula dengan yang 
selanjutnya. ${ }^{4}$

Menurut Hurlock ada tujuh prinsip-prinsip dari perkembangan yaitu sebagai berikut:

a. Adanya perubahan. Manusia tidak akan mungkin pernah didalam keadaaan statis, manusia akan sering berubah ubah serta mengalami perubahan dimulai sejak pertama pembuahan sampai pada akhirnya kematian tiba. Ada yang menanjak, di titik puncak, serta dititik kemunduran. Proses perkembangan pada anak ada beberapa cirri perubahan yang sangat mencolok, sebagai berikut: perubahan fisik meliputi: berat, tinggi, perubahan mental ( memori, persepsi, penalaran, serta imajinasi), perubahan organ dalam tubuh. Perubahan proporsi ( perubahan perbandingan antara kepala serta tubuh anak). Hilangnya sikap egosentrisme berubah menjadi sikap prososial.

b. Perkembangan awal lebih kritis dari pada perkembangan berikutnya. Adapun lingkungan masa kecilnya sangat berpengaruh terhadap kemampuan bawaan anak tersebut. Terdapat bukti-bukti ilmiah yang menunjukakn bahwa dasar awal lebih cenderung bertahan serta sangat mempengaruhi sikap anak sepanjang ia hidup.

c. Perkembangan itu adalah hasil dari proses kematangan dan belajar. Proses kematang dapat diartikan sebagai proses terbukanya karakteristik yang secara potensi sudah ada pada anak yang diwariskan oleh genetic anak. Contohnya dalam merangkak, duduk selanjutnya berjalan. Sedangkan belajar dapat diartikan sebagai perkembangan yang berasal dari latihan serta usaha yang dilakukan oleh anak tersebut. Melalui belajar anak akan mandapatkan kemampuan dalam menggunakan sumber yang sudah diwariskan. Adapun hubungan kematangan dan belajar dapat dilihat pada saat masa pekanya, ketika pembelajaran diberikan pada masa peka maka hasil dari pembelajarannya akan terlihat dan cepat dikuasai oleh anak.

d. Pola perkembangan bisa diramalkan. Yang pertama Perkembangan yang menyebar diseluruh tubuh anak dari kepala sampai ke kaki. Hal ini menunjukkan bahwa kemajuan didalam struktur serta fungsinya awalnya terjadi pada bagian

${ }^{4}$ Yudrik Jahja, “Psikologi Perkembangan” (Jakarta: Kencana Prenada Group, 2011), hlm. 23. 
kepala, badan, serta kaki yang terakhir. Yang kedua adalah perkembangannya dari dekat ke yang jauh. Jari jemari anak akan akan didahului oleh keterampilan lengan anak.

e. Pola perkembangan memiliki karakteristik yang bisa diramalkan. Adapun terdapat karakteristik tertentu yang bisa diramalkan. Hal ini berlaku tidak hanya fisik akan tetapi juga mental, setiap anak mengikuti perkembangan dengan pola yang sama dari satu tahap ketahap selanjutnya. Bayi berdiri sebelum bisa berjalan, dan pola ini tidak akan pernah berubah walaupun terdapat bermacam anak didalam kecepatan perkembanganya. Anak yang pintar serta anak yang kurang pintar pasti urutan perkembanganya yang sama. Akan tetapi terdapat perbedaan anak yang pandai biasanya lebih cepat didalam perkembangannya jika dibandingkan dengan anak yang kurang pintar, begiti juga sebaliknya. Begituja dalam perkembangan bergerak yaitu dari dari yang umum ke yang lebih khusus. Contohnya bayi akan mengobrak abrik mainan sebelum anak ini bisa melakukan permainannya. Seperti itu juga dalam perkembangan emosi, anak akan cepat merespon ketakutan secara umum terhadap hal yang baru berikutnya barulah ketakutan secara khusus. Perkembangan akan berlangsung dengan cara bertahap dimulai dari pembuahan sampai kematian, akan tetapi hal ini akan terjadi terkadang cepat dan terkadang lambat.

f. Terdapat perpedaan individu didalam perkembangan.

g. Setiap tahap perkembangan mempunyai bahaya yang potensial. Perkembangan itu tidak selamanya berjalan sesuai dengan rencana ataupun mulus. Di setiap usia terdapat bahaya yang bisa menggangu pola normal dari perkembangan itu. Adapun hal yang bisa menyebabkan itu adalah tidak lain adalah ingkungan anak itu sendiri. Bahaya tersebut mampu menghambat penyesuaian fisik, psikologis, serta sosialnya. Sehingga pola perkembangan anak ini bukan naik akan tetapi datar yang artinya tidak terdapat peningkatan dalam perekembangannya. 


\section{Perkembangan sosial emosional}

Emosi merupakan suatu keadaan yang ada pada diri seseorang yang meliputi perubahan secara badaniah maupun kondisi mental yang nantinya menimbulkan rasa seperti sedih, marah, bahagia, dan sebagainya. Emosi anak itu timbul dikarenakan ketidak siapan anak dalam menyikapi kondisi lingkungan sekitar. Oleh karena itu orang tua dan guru sebagai orang dewasa disekitar anak tersebut, memegang peranan penting dalam mengoptimalkan potensi anak, baik fisik, kognif, spiritual, maupun emosi itu sendiri.

Adapun perkembangan emosi anak dipengaruhi oleh factor kematangan dan factor belajar. Factor kematangan berpengaruh terhadap respon individu dalam menyikapi berbagai keadaan yang dihadapi, baik dari dalam diri maupun konflik-konflik dalam proses perkembangan yang terjadi. Sedangkan factor belajar diperoleh dari lingkungan yang ada disekitar anak, terutama lingkungan yang berada dalam mikrosistem, mesosistem, ekosistem, makrosistem, dan kronosistem. ${ }^{5}$

Adapun tekanan yang diberikan terhadap anak prasekolah berbeda dengan anakanak yang sudah sekolah ataupun dewasa. Menurut Ericson, santrek, marisson fase perkembangan anak pada aspek social emosi terbagi menjadi tiga tahapan yaitu:

a. Masa bayi (usia 0-18 bulan) yaitu tahap terbentuknya kepercayaan terhadap sesuatu yang menimbulkan kenyamanan terhadap diri si bayi tersebut.

b. Masa toddlers (usia 18 bulan- 3 tahun) pada tahap ini mulai terbentuknya rasa kemandirian ataupun kemauan yang berasal dari diri sendiri, sehingga jika si anak terlalu dipaksakan maka akan timbul rasa malu, ragu-ragu atau bahkan rasa takut.

c. Masa anak-anak atau prasekolah (usia 3 tahun -6 tahun) pada tahap ini terbentuknya aktifitas atau perilaku lebih misalnya rasa bersalah.

Oleh karena itu biasanya pada usia lima tahun pertama itu adalah usia dimana anak sudah biasa menyikapi kondisi lingkungan sekitar ataupun periode dimana anak anak telah mencapai kematangan atau kesiapan untuk belajar sesuatu.

Maka dari itu perlu adanya lingkungan yang baik untuk perkembangan anak baik prasekolah maupun sudah sekolah atau bahkan anak yang sudah dewasa sekalupun.

5 Riana Masher, "Emosi Anak Usia Dini Dan Pengembangannya" (Jakarta: Kencana Prenada Group, 2011), Hlm. 102. 
Karena pertumbuhan anak itu baik atau tidaknya prilaku yang ia miliki tergantung pada lingkungan sekitarnya. Begitu juga dengan emosi, dibutuhkan lingkungan yang mendukung agar anak mendapatkan emosi yang baik yang sesuai dengan kapasitas anak tersebut.

Social emosional pada anak sekolah dasar, perkembangan sosialnya sudah mulai bisa berkompetensi dengan teman sebaya, mempunyai sahabat, telah mampu mandiri dan berbagi. Sementara dari segi emosionalnya anak sekolah dasar sudah dapat mengekspresikan maupun mengontrol emosinya melalui meniru maupun pembiasaan.

Social emosional pada anak usia dasar juga di tandai dengan kematangan dalam interaksi socialnya, bagaimana anak bergaul, beradaptasi dengan lingkungan serta menyesuaikan diri terhadap norma-norma kelompok. Perkembangan social anak sangat tergantung kepada lingkungan social dimana anak berada baik keluarga, teman sebaya, guru dan masyarakat sekitar. Sedangkan perkembangan emosi tergantung pada factor kematangan dan factor belajar. Untuk mencapai kematangan emosi anak harus belajar memperoleh gambaran tentang situasi yang dapat menimbulkan reaksi emosional dengan cara menceritakan masalah yang anak hadapi kepada orang lain (keterbukaan) sehingga anak merasa tenang. ${ }^{6}$

Oleh karena itu perkembangan social emosional sangat dipengaruhi oleh factor lingkungan, keluarga. Dengan demikian penting bagi orang tua ataupun orang yang ada disekitarnya menciptakan lingkungan yang dapat merangsang pertumbuhan dengan baik. Kematangan social adalah suatu perkembangan pada saat anak mencapai kemampuan untuk hidup bermasyarakat yang arahnya ditentukan oleh tuntutan social dalam keluarga,teman sebaya, guru mapun lingkungan sekitar. Kematangan social akan didapat melalui kinerja yang menunjukkan perkembangan kemampuan dalam memelihara diri sendiri serta kemampuan berpartisipasi didalam aktifitas yang mendukung perkembangan social emosional tersebut. ${ }^{7}$

Kematangan social juga sangat penting untuk dikembangkan pada anak karena merupakan kemampuan yang akan membantu kemandirian social dan mencerminkan perkembangan dan kompetensi social anak. Kematangan social anak akan didapat

\footnotetext{
${ }^{6}$ Umi Latifa, "Aspek Perkembangan Pada Anak Sekolah Dasar Masalah Dan Perkembanganya," Jurnal Academica Vol I No.2 (n.d.): 189-192.

7 Yeniar Indriana, "Mengembangakan Kematangan Social Emosional Pada Anak Melalui Outbound," Jurnal Sekolab Dasar No.2 (2008): 151.
} 
melalui interaksi anak seperti didalam outbound. Aktifitas-aktifitas yang dilakukan anak dalam kegiatan tersebut menuntut kerja sama tim serta harus adanya rasa saling percaya antar sesama anak yang mengikuti outbound. Hal tersebut dapat mendorong anak untuk dapat berinteraksi dengan orang lain. Interaksi social yang baik akan menstimulasi kematangan social anak. Adapun outbound adalah salah satu cara untuk mengembangankan kematangan social anak sehingga bisa membantu anak yang mempunyai masalah dengan hubungan social dan melatih anak dalam kemandirian.

Perkembangan social emosional sangat tergantung dari interaksinya dengan orang lain. Artinya emosional yang merupakan proses mental ini akan berkembang tergantung dari proses belajar dari lingkunganya. ${ }^{8}$ EP has the potential to be a valuable tool to enhance students' socio-emotional development, to promote greater understanding by teachers of the psychological lives of their students, and to enhance the quality of the teacher-student relationship. The stories and group processing aspects of EP seem appropriate for two very different cultural and educational contexts. Yang intinya bahwa ada beberapa hal yang bisa meningkatkan social emosional anak akan tetapi peran lingkungan pendidik atau guru maupun orang tua harus mampu memberikan pemahaman yang lebih besar agar anak dapat mengarahkan emosionalnya kearah yang positif sehingga sosialnya pun baik. Sosial emosional merupakan suatu proses dimana anak-anak mampu mengembangkan kemampuan mereka dalam mengontrol pikiran, perasaan serta prilaku, sehingga social emosional tersebut dapat terealisasikan dengan baik. Social emosional yang baik adalah social emosional yang mampu menciptakan hubungan yang sehat dengan orang lain. Oleh sebab itu pendidik atau guru adalah orang yang berada disekitar anak sangat berperan penting dalam pembentukan social emosional anak.

8 Yuli Setiyowati, "Pola Komunikasi Keluarga Dan Perkembangan Emosi Anak ( Studi Kasus Penerapan Pola Komunikasi Keluarga Dan Pengaruhnya Terhadap Perkembangan Emosi Anak Pada Keluarga Jawa"," Jurnal Imu Komunikasi Vol 2 No.1 (2005): 73.

9 Chiaki Konishi, "Promoting Childrens Healty Social Emotional Growth Dialogue Journal," Journal Of Education And Learning Vol 6 No.2 (2017): 247. 


\section{Lingkungan keluarga}

a. Pengertian keluarga

Menurut F.J Brown keluarga dapat diartikan dari sudut pandang sosiologis ada dua macam yaitu dalam arti yang sangat luas keluarga meliputi seluruh pihak yang memiliki hubungan darah maupun marga. Adapun dalam arti sempit keluarga meliputi orang tua serta anak. Sedang Maciver berpendapat bahwa keluarga memiliki lima cirri khas yang umum yaitu hubungan yang berpasangan laki-laki dan perempuan. Kemudian ikatan perkawinan yang mampu memperkuat hubungan tersebut. Pengakuan dengan adanya keturunan. Kehidupan yang dinikmati serta diselengara bersama serta kehidupan berumah tangga.

Menurut sigelman \& Shaffer keluarga adalah unit social terkecil yang bersifat menyeluruh, maknanya ada pada setiap masyarakat di dunia maupun suatu system social yang terbentuk didalam system social yang lebih besar.

b. Fungsi dan peranan keluarga

Keluarga dapat dipandang sebagai pondasi utama dalam pembentukan kepribadian anak termasuk social emosianal anak. Dikarenakan keluarga adalah kelompok anggota social yang paling pertama yang menjadi objek identifikasi anak. Anak juga lebih banyak menghabiskan waktunya didalam lingkungan keluarga. Serta semua anggota keluarga adalah "signifikan people" untuk pembentukan kepribadian anak. ${ }^{10}$

Keluarga juga dipandang sebagai lembaga yang mampu memenuhi kebutuhan insane (manusiawi), yang terutama bagi pengembangan kepribadian serta pengembangan rasa manusia (anak), anak mampu memenuhi kebutuhannya baik itu kebutuhan fisik dan biologis, maupun itu kebutuhan sosia dan psikologis. Jika anak sudah mampu memenuhi kebutuhan dasarnya, maka anak itu cenderung menjadi seorang pribadi yang sehat.

Adapun perlakuan orang tua terhadap anaknya yang penuh dengan kasih saying serta pendidikan nilai-nilai kehidupan, baik itu nilai spriritual mapun nialai social budayanya, itu adalah factor yang kondusif guna mempersiapkan anak menjadi pribadi serta warga masyarakat yang sehat serta produktif. Suasana didalam keluarga sangatlah penting dalam perkembangan kepribadian anak termasuk pribadi yang memiliki social emosional yang baik.

10 Syamsu Yusuf \& Juntika Nurihsan, “Teori Kepribadian” (Bandung: Remaja Rosda Karya, 2011), Hlm. 52. 
Anak yang dibesarkan didalam lingkungan keluarga yang harmonis serta aagamanya kuat, adapun seperti suasana yang mampu memberikan, perhatian, curahan kasih saying, serta bimbingan dalam lingkup agama. Maka perkembangan kepribadian yaitu social emosional anak tersebut akan mengarah ke pada hal yang positif, dan sehat.

Sedangkan jika anak dibesarkan didalam lingkungan keluarga yang broken home, yang kurang harmonis, maupun keluarga yang tidak mau memperhatikan nilai-nilai agama, maka bisa jadi perkembangan kepribadiannya juga cenderung akan mengalami kelainan dalam menyesuaikan dirinya. Gambaran pengaruh lingkungan keluarga terhadap kepribadian anak yaitu social emosional anak menurut Dorothy Law Nolte bahwasannya: anak belajar dari kehidupannya, sebagai berikut:

1) Jika anak dibesarkan dengan celaan, anak belajar memaki.

2) Jika anak dibesarkan dengan permusuhan, anak belajar berkelahi.

3) Jika anak dibesarkan dengan cemoohan, anak belajar rendah diri.

4) Jika anak dibesarkan dengan penghinaan, anak belajar menyesali diri

5) Jika anak dibesarkan dengan toleransi, anak belajar menahan diri.

6) Jika anak dibesarkan dengan dorongan, anak belajar percaya diri.

7) Jika anak dibesarkan dengan pujian, anak belajar menghargai.

8) Jika anak dibesarkan dengan sebaik-baik perlakuan, anak belajar keadilan.

9) Jika anak dibesarkan dengan dukungan, anak belajar menyayangi dirinya.

10) Jika anak dibesarkan dengan kasih saying dan persahabatan, anak belajar menemukan cinta.

Menurut Baldwin bahwasannya pola asuh didalam keluarga khususnya orang tua ada yang demokratis dan ada juga yang authoritarian. Adapun orang tua yang demokratis itu ditandai dengan perilaku yang mampu menciptakan iklim kebebasan, bersikap peduli terhadap anak, mampu mengambil keputusan dengan cara rasional, serta objektif. Sedangkan orang tua yang authoritarian ditandai dengan sikap yang sesuka hatinya (dictator) didalam memberikan perlakuan terhadap anak. Anak yang dibesarkan dalam lingkungan demokratis akan mempunyai kepribadian lebih social, aktif, percaya diri, keinginan dalam bidang intelektual, orsinil, serta lebih konstruktif dibandingkan dengan anak yang dibesarkan 
dilingkungan keluarga dalam iklim authoritarian.

\section{KESIMPULAN}

Kesimpulan yang dapat diambil dari uraian diatas Perkembangan adalah hal yang berkaitan dengan perubahan kualitatif serta kuantitatif yaitu urutan progresif dari perubahan yang teratur serta koheren. Ada beberapa karakteristik dari perkembangan perkembangan yaitu sebagai berikut:

a. Perkembangan itu berlangsung dimulai dari hal-hal yang bersifat umum kemudian ke sifat khusus.

b. Perkembangan itu bersifat berkesinambungan.

c. Setiap bagian tubuh memiliki kecepatan pertumbuhan masing-masing. Selalu ada hubungan antara perkembangan yang semula dengan yang selanjutnya.

Emosi merupakan suatu keadaan yang ada pada diri seseorang yang meliputi perubahan secara badaniah maupun kondisi mental yang nantinya menimbulkan rasa seperti sedih, marah, bahagia, dan sebagainya. Social emosional pada anak sekolah dasar, perkembangan sosialnya sudah mulai bisa berkompetensi dengan teman sebaya, mempunyai sahabat, telah mampu mandiri dan berbagi. Oleh karena itu peran keluarga sangatlah penting terhadap perkembangan social emosional anak terlebih lagi pada anak usia dasar. Orang tua maupun saudara yang ada dilingkungan keluarga tersebut harus sangat memeperhatikan dan peduli terhadap anak agar anak mampu mengontrol emosionalnya sehingga nantinya akan mampu menghasilkan social yang baik dan mampu menjadi teladan bagi siapapun yang melihat anak tersebut. Bukan saja keluarga yang senang maupun mengingin anak yang sosialnya baik dan mampu mengontrol emosinya, akan tetapi orang lain yang ada disekitar pekarang rumah tempat anak itu tinggal juga akan menjadikan anak tersebut sebagai suri tauladan bagi anak-anak mereka.

\section{DAFTAR PUSTAKA}

Eka Tusyana, Dkk. “'Analisis Perkembangan Social Emosional Tercapai Usia Dasar."” Jurnal Inventa Vol III No (2019): 21-22.

Indriana, Yeniar. "Mengembangakan Kematangan Social Emosional Pada Anak Melalui 
Outbound.” Jurnal Sekolah Dasar No.2 (2008): 151.

Jahja, Yudrik. "Psikologi Perkembangan,” 23. Jakarta: Kencana Prenada Group, 2011.

Konishi, Chiaki. "Promoting Childrens Healty Social Emotional Growth Dialogue Journal." Journal Of Education And Learning Vol 6 No.2 (2017): 247.

Latifa, Umi. "Aspek Perkembangan Pada Anak Sekolah Dasar Masalah Dan Perkembanganya." Jurnal Academica Vol I No.2 (n.d.): 189-92.

Masher, Riana. "Emosi Anak Usia Dini Dan Pengembangannya," 3. Jakarta: Kencana Prenada Group, 2011.

_. "Emosi Anak Usia Dini Dan Pengembangannya," Hlm. 102. Jakarta: Kencana Prenada Group, 2011.

Prastowo, A. Menyusun Rencana Pelaksanaan Pembelajaran (RPP) Tematik Terpadu. Jakarta: Prenada Media Group, 2017.

Setiyowati, Yuli. "Pola Komunikasi Keluarga Dan Perkembangan Emosi Anak ( Studi

Kasus Penerapan Pola Komunikasi Keluarga Dan Pengaruhnya Terhadap Perkembangan Emosi Anak Pada Keluarga Jawa"." Jurnal Ilmu Komunikasi Vol 2 No.1 (2005): 73.

Syamsu Yusuf \& Juntika Nurihsan. “Teori Kepribadian,” Hlm. 52. Bandung: Remaja Rosda Karya, 2011. 